\title{
Penerapan Model Pembelajaran Make-A Match untuk Meningkatkan Prestasi Belajar Siswa pada Tema Pengalamanku
}

\section{Putu Sukerni \\ SD Negeri 4 Kaliuntu Singaraja}

\section{A R T I C L E I N F O}

Article history:

Received 12 December 2019

Received in revised form 01 January 2020

Accepted 30 January 2020

Available online 27

February 2020

\section{Kata Kunci:}

Model Pembelajaran

Make-A Match, Prestasi

Belajar

Keywords:

Make-A Match Learning

Model, Learning

Achievement

\begin{abstract}
A B S T R A K
Penelitian ini dilatar belakangi oleh rendahnya prestasi belajar siswa kelas I SD Negeri 4 Kaliuntu. Penelitian ini bertujuan untuk meningkatan prestasi belajar siswa dengan penerapan model pembelajaran Make-A Match siswa kelas I di SD Negeri 4 Kaliuntu, Kecamatan Buleleng, Kabupaten Buleleng tahun pelajaran 2018/2019. Penelitian ini adalah penelitian tindakan kelas yang dilaksanakan dalam dua siklus. Setiap siklus terdiri atas tahap perencanaan, tindakan, observasi/evaluasi, dan refleksi. Subjek penelitian ini adalah siswa kelas I di SD Negeri 4 Kaliuntu, Kecamatan Buleleng, Kabupaten Buleleng tahun pelajaran 2018/2019 sebanyak 31 orang siswa. Pengumpulan data dalam penelitian ini dilakukan dengan menggunakan lembar evaluasi. Data yang dikumpulkan dianalisis dengan menggunakan metode analisis stasistik deskriptif dan analisis deskriptif kuantitatif. Hasil penelitian menunjukan bahwa pembelajaran tematik dengan menggunakan model pembelajaran Make-A Match dapat meningkatkan kemampuan prestasi belajar siswa kelas I di SD Negeri 4 Kaliuntu, Kecamatan Buleleng, Kabupaten Buleleng tahun pelajaran 2018/2019. Pada siklus I rata-rata prestasi belajar siswa sebesar 63,84 pada kategori kurang dan meningkat menjadi 80,19 pada siklus II yang berada pada kategori baik
\end{abstract}

\section{A B S T R A C T}

This research is motivated by the low learning achievement of students in grade I SD Negeri 4 Kaliuntu. This study aims to increase student learning achievement by applying the Make-A Match learning model for grade I students at SD Negeri 4 Kaliuntu, Buleleng District, Buleleng Regency in the academic year 2018/2019. This research is a classroom action research conducted in two cycles. Each cycle consists of the stages of planning, action, observation / evaluation, and reflection. The subjects of this study were class I students at SD Negeri 4 Kaliuntu, Buleleng District, Buleleng Regency in the 2018/2019 academic year as many as 31 students. Data collection in this study was carried out using an evaluation sheet. Data collected were analyzed using descriptive statistical analysis methods and quantitative descriptive analysis. 


\section{Pendahuluan}

Pendidikan dapat mempengaruhi perkembangan manusia dalam seluruh aspek kepribadian dan kehidupannya. Pendidikan memiliki kekuatan ( pengaruh ) yang dinamis dalam kehidupan manusia di masa depan. Pendidikan dapat mengembangkan berbagai potensi individu yang dimilikinya secara optimal, yaitu pengembangan potensi individu yang setinggi-tingginya dalam aspek fisik, intelektual, emosional, sosial, dan spiritual, sesuai dengan tahap perkembangan serta karakteristik lingkungan fisik dan lingkungan sosiobudaya dimana dia hidup. Pendidikan adalah sesuatu yang kompleks, oleh karena itu maka pendidikan dapat dilihat dan dijelaskan dari berbagai sudut pandang, seperti dari sudut pandang psikologi, sosiologi, dan antropologi, ekonomi, politik, komunikasi, dan sebagainya. Oleh karena itu pula, definisi yang dikemukakan oleh para ahli sangat beragam, sehingga cukup sulit menemukan definisi yang representatif yang dapat diterima oleh seluruh pihak. Betapapun sulitnya mendefinisikan pendidikan, namun untuk keperluan aplikasinya tetap perlu memiliki pegangan tertentu. Salah satu pengertian yang sangat umum dikemukakan oleh Driyarkora (1980) yang menyatakan bahwa pendidikan adalah upaya memanusiakan manusia muda, yang harus diwujudkan di dalam seluruh proses atau upaya pendidikan.

Belajar sendiri menurut Gagne dalam Suprijono (2009:2) Belajar adalah perubahan disposisi atau kemampuan yang dicapai seseorang melalui aktivitas. Deresta (dalam Armini, 2009:2) mengemukakan kondisi belajar yang optimal dapat dicapai jika guru mampu mengatur siswa, sarana pengajaran serta mengendalikannya dalam suasana belajar yang menyenangkan untuk mencapai tujuan. Pengaturan yang dimaksud bersifat lebih langsung berkenaan dengan penyampaian peran pengajaran yang sepenuhnya merupakan penyediaan kondisi yang menguntungkan, yang dinamakan pengelolaan kelas.

Berdasarkan observasi awal, terkait dengan prestasi belajar siswa teridentifikasi beberapa masalah yang terjadi di kelas I diantaranya :

a. Kemampuan siswa yang beraneka ragam

Kemampuan siswa ada yang sangat pintar, sedang dan kurang. Hasil observasi awal menunjukkan, dari 31 orang siswa hanya 16 orang yang sudah mendapatkan nilai di atas KKM dan 15 orang yang mendapatkan niai di bawah KKM.

b. Perhatian siswa kurang dalam proses pembelajaran,

c. Antusias siswa dalam proses pembelajaran masih kurang,

d. Hanya sebagian siswa yang dapat menjawab dan melaksanakan perintah guru,

e. Kegiatan belajar masih belum menyenangkan

Guru perlu melakukan kegiatan bermain sambil belajar agar pembelajaran tidak cepat membosankan.

f. Siswa merasa terbebani pada saat mengerjakan evaluasi pembelajaran.

Mengacu pada permasalahan di atas, maka perlu dicari solusi dalam meningkatkan prestasi belajar siswa. Salah satu metode yang dapat digunakan adalah metode pembelajaran Make-A Macth. Model pembelajaran adalah suatu perencanaan atau suatu pola yang digunakan sebagai pedoman dalam merencanakan pembelajaran di kelas atau pembelajaran dalam tutorial, Joyce (Trianto 2010: 22). Model pembelajaran Make-A Match atau mencari pasangan merupakan suatu model pembelajaran yang mengajak peserta didik mencari jawaban terhadap suatu pertayaan atau pasangan dari suatu konsep melalui suatu permainan kartu pasangan. Model pembelajaran Make-A Match adalah cara menyenangkan meninjau ulang materi pembelajaran dengan memberi kesempatan kepada peserta didik untuk berpasangan dan memainkan kuis kepada kawan sekelas.

Model pembelajaran Make-A Match merupakan salah satu pembelajaran dengan pendekatan PAIKEM yaitu pembelajaran yang melibatkan siswa secara aktif dalam berbagai kegiatan pembelajaran baik secara individu maupun kelompok, sehingga dapat mengembangkan pemahaman dan kemampuan belajar melalui berbuat atau melakukan.

Dengan menggunakan model pembelajaran kooperatif teknik make a match siswa akan lebih bersemangat karena model pembelajaran tersebut terdapat unsur permainannya, selain itu siswa pun dilibatkan langsung dalam pembelajaran. Teknik make a match ini mampu menciptakan kondisi kelas yang interaktif, efektif sebagai sarana untuk melatih keberanian siswa, serta mampu menghilangkan kebosanan siswa ketika pembelajaran berlangsung (Deschuri, 2016).

Model pembelajaran make a match ialah model pembelajaran secara berkelompok yang mengajak siswa untuk memahami konsep dan topik pembelajaran dalam situasi yang mengasyikkan melalui media kartu jawaban dan kartu pertanyaan. Dalam pelaksanaannya, model ini memiliki batasan waktu maksimum yang sudah ditentukan sebelumnya. Kelebihan dari model pembelajaran make a match, diantaranya: (1) mewujudkan kondisi pembelajaran yang mengasyikkan; (2) materi belajar disajikan lebih menarik perhatian peserta didik; (3) dapat memperbaiki hasil beljar peserta didik guna mencapai taraf ketuntasan belajar; (4) Kerjasama antarsesama peserta didik terwujud dengan dinamis (Kurniasih 
dan Berlin, 2015: 56). Dari beberapa kelebihan yang dimiliki oleh pembelajaran kooperatif tipe make a match, pembelajaran IPS diharapkan menjadi lebih bermakna untuk siswa. Siswa ikut terlibat aktif saat kegiatan pembelajaran, hingga siswa merasa gembira, asyik, dan berminat dalam menerima materi pelajaran. Diskusi yang terdapat pada model pembelajaran kooperatif tipe make a match ini dapat membuat siswa mudah memahami konsep-konsep IPS dan memunculkan banyak ide. Selain itu, adanya peraturan, menunggu giliran bermain, menemukan kecocokan pasangan kartu juga akan membantu siswa mendapatkan keterampilan social (Riyanti, 2018).

Berdasarkan permasalahan tersebut akan dilakukan kerjasama yang maksimal semua pihak serta guru dan siswa melalui Penelitian Tindakan Kelas. Berdasarkan uraian di atas dilaksanakan penelitian yang berjudul "Penerapan Model Make-A Match Untuk Meningkatkan Prestasi Belajar Pada Tema Pengalamanku di kelas I Semester II SD Negeri 4 Kaliuntu Tahun Pelajaran 2018/2019".

Mifathul Huda (2012: 135) menyatakan bahwa teknik Make-A Match dikembangkan oleh Lorna Curran (1994), teknik ini dilakukan dengan siswa mencari pasangan dari kartu soal/jawaban yang dimiliki sambil mempelajari suatu konsep atau topik tertentu dalam suasana yang menyenangkan. Model pembelajaran Make-A Match atau mencari pasangan merupakan suatu model pembelajaran yang mengajak peserta didik mencari jawaban terhadap suatu pertayaan atau pasangan dari suatu konsep melalui suatu permainan kartu pasangan. Model pembelajaran Make-A Match adalah cara menyenangkan meninjau ulang materi pembelajaran dengan memberi kesempatan kepada peserta didik untuk berpasangan dan memainkan kuis kepada kawan sekelas. Menurut Rusman (2012) mengatakan salah satu keunggulan model pembelajaran ini adalah siswa mencari pasangan sambil belajar mengenai suatu konsep atau topik dalam suasana yang menyenangkan. Menurut Kurniasih dan Sani (2015:56), model pembelajaran kooperatif tipe Make-A Match memiliki kelebihan, diantaranya: (1) menciptakan suasana belajar aktif dan menyenangkan di dalam kelas, (2) materi pembelajaran yang disampaikan oleh guru menjadi lebih menarik perhatian siswa.

Adapun teknik pembelajaran dengan model Make-A Match adalah sebagai berikut:

a. Guru menyiapkan beberapa kartu yag berisi beberapa konsep atau topik yg cocok untuk sesi review, satu bagian kartu soal dan bagian lainnya kartu jawaban

b. Setiap peserta didik mendapat satu buah kartu

c. Setiap peserta didik memikirkan jawaban/soal dari kartu yg dipegang

d. Setiap siswa mencari pasangan yag mempunyai kartu yag cocok dengan kartunya (soal jawaban)

e. Setiap siswa yang dapat mencocokkan kartunya sebelum batas waktu diberi poin

f. Setelah satu babak kartu ditukar/dikocok agar tiap siswa mendapat kartu yang berbeda dari sebelumnya

g. Demikian seterusnya

h. Kesimpulan/penutup

Model Pembelajaran Make-A Match memberikan manfaat bagi siswa, diantaranya sebagai berikut:

a. Mampu menciptakan suasana belajar yang aktif dan menyenangkan

b. Meteri pembelajaran yang disampaikan lebih menarik perhatian siswa

c. Mampu meningkatkan hasil belajar siswa mencapai taraf ketuntasan belajar secara klasikal.

d. Suasana kegembiraan akan tumbuh dalam prosespembelajaran

e. Kerjasama antar sesama siswa terwujud dengan dimanis

f. Munculnya dinamika gotong royong yang merata diseluruh siswa.

Model Pembelajaran Make-A Match mempunyai kelemahan, diantaranya sebagai berikut:

a. Sangat memerlukan bimbingan guru untuk melakukan kegiatan

b. Guru perlu mempersiapkan bahan dan alat yang memadai

c. Pada kelas dengan jumlah murid yang banyak ( lebih dari 30 orang) jika kurang bijaksana maka akan muncul suasana seperti pasar dengan keramaian yang tidak terkendali.

d. Bisa mengganggu ketenangan belajar kelas di kiri kanannya.

\section{Metode}

Penelitian ini dilaksanakan pada semester genap tahun pelajaran 2018/2019. Jenis penelitian menggunakan penelitian tindakan kelas. Menurut Wina (2016: 2) menyebutkan PTK merupakan salah satu teknik agar pembelajaran yang dikelola guru selalu mengalami peningkatan melalui perbaikan secara terus menerus.Penentuan waktu penelitian mengacu kepada kalender pendidikan SD Negeri 4 Kaliuntu. Penelitian tindakan kelas ini dilaksanakan di SD Negeri 4 Kaliuntu Kecamatan Buleleng Kabupaten Buleleng tahun pelajaran 2018/2019 di kelas 1. Obyek penelitian ini adalah prestasi belajar siswa setelah penerapan Model Pembelajaran Make-A Match. Subjek penelitian ini adalah siswa kelas I 
semester genap SD Negeri 4 Kaliuntu tahun pelajaran 2018/2019. Jumlah siswa yang menjadi subjek penelitian adalah 31 orang. Jenis penelitian ini adalah penelitian tindakan kelas (PTK).

Menurut Santyasa (dalam Tegeh, 2011:3) "PTK didefinisikan sebagai suatu bentuk kajian yang bersifat reflektif oleh pelaku tindakan". Tindakan tersebut dilakukan untuk meningkatkan kemantapan rasional dari tindakan-tindakan dalam melaksanakan tugas sehari-hari, memperdalam pemahaman terhadap tindakan-tindakan yang dilakukan, serta memperbaiki kondisi di mana praktik-praktik pembelajaran tersebut dilakukan. Penelitian ini dilaksanakan dalam dua siklus. Jumlah pertemuan tiap siklus adalah dua kali pertemuan untuk mengadakan pembelajaran. Tiap siklus terdiri dari empat tahapan yaitu: Perencanaan, Pelaksanaan, Observasi/Evaluasi, dan Refleksi. Dalam PTK terjadi kerjasama antara peneliti dengan guru dan dua orang observer yang membantu dalam pengamatan untuk mengambil data selama penelitian (Wiraatmadja, 2007).

Agung (2005:60) menyatakan bahwa, Metode analisis statistik deskriptif adalah cara pengolahan data yang dilakukan dengan jalan menerapkan rumus-rumus statistik deskriptif seperti distribusi frekuensi, grafik, angka rata-rata (Mean), median (Me), dan Modus (Mo) untuk menggambarkan keadaan suatu objek tertentu sehingga diperoleh kesimpulan umum. Agung (2005:96) menyatakan bahwa, Metode analisis deskriptif kuantitatif adalah suatu cara pengolahan data yang dilakukan dengan jalan menyusun secara sistematis dalam bentuk angka-angka dan atau persentase mengenai keadaan suatu objek yang diteliti sehingga diperoleh kesimpulan umum.

Pada penelitian ini metode yang digunakan untuk menganalisis data ini adalah metode analisis statistik deskriptif dan analisis deskriptif kuantitatif. Kriteria yang digunakan untuk menunjukkan keberhasilan tindakan ini adalah terjadinya perubahan/peningkatan prestasi belajar siswa dalam pembelajaran. Sistem penilaian dalam penelitian ini berpedoman pada Kriteria Ketuntasan Minimal (KKM) Satuan Pendidikan SD Negeri 4 Kaliuntu yaitu 65. Peningkatan nilai prestasi belajar secara ratarata meningkat minimal sampai pada kategori "baik" dengan tingkat penguasaan (80 sampai dengan 89). Hasil belajar adalah kemampuan yang dimiliki siswa setelah ia menerima pengalaman belajarnya (Sudjana,2010). Apabila indikator keberhasilan pada pencapaian penguasaan materi sudah tercapai, maka penelitian dapat dihentikan dan akan dijadikan simpulan dan pembahasan bahwa siklus tersebut telah tercapai.

\section{Hasil dan Pembahasan}

Penelitian ini dilaksanakan dalam 2 siklus. Setiap siklus dilaksanakan dalam 3 kali pertemuan yaitu 2 kali proses pembelajaran dan 1 kali tes akhir siklus. Data yang telah dikumpulkan dalam penelitian ini yaitu data tentang prestasi belajar siswa kelas I SD Negeri 4 Kaliuntu. Pelaksanaan siklus I penerapan model pembelajaran Make-A Match dilaksanakan dari 7 Januari 2019 sampai dengan 26 Januari 2019. Objek penelitian ini adalah prestasi belajar siswa kelas I SD Negeri 4 Kaliuntu yang berjumlah 31 orang. Siklus 1 dibagi menjadi tiga kali pertemuan yaitu pertemuan 1 dilaksanakan pada Senin 7 Januari 2019, pertemuan 2 dilaksanakan pada hari Kamis 10 Januari 2019 dan tes siklus I dilaksanakan pada hari Jumat 18 Januari 2019. Adapun hasil penelitian prestasi belajar siswa diuraikan pada penjelasan di bawah ini.

Nilai prestasi belajar siswa pada siklus I disajikan pada Tabel 1 di bawah ini.

Tabel 1. Prestasi Belajar Siswa pada Siklus I

\begin{tabular}{cccc}
\hline No & Kode Subjek & Nilai & Keterangan \\
\hline 1 & 01 & 53 & Tidak tuntas \\
2 & 02 & 80 & Tuntas \\
3 & 03 & 80 & Tuntas \\
4 & 04 & 67 & Tuntas \\
5 & 05 & 53 & Tidak tuntas \\
6 & 06 & 80 & Tuntas \\
7 & 07 & 73 & Tuntas \\
8 & 08 & 53 & Tidak tuntas \\
9 & 09 & 93 & Tuntas \\
10 & 010 & 73 & Tuntas \\
11 & 011 & 67 & Tuntas \\
12 & 012 & 47 & Tidak tuntas \\
13 & 013 & 33 & Tidak tuntas \\
14 & 014 & 67 & Tuntas \\
15 & 015 & 73 & Tuntas \\
\hline
\end{tabular}




\begin{tabular}{lllc}
\hline 16 & 016 & 40 & Tidak tuntas \\
17 & 017 & 40 & Tidak tuntas \\
18 & 018 & 73 & Tuntas \\
19 & 019 & 53 & Tidak Tuntas \\
20 & 020 & 47 & Tidak Tuntas \\
21 & 021 & 53 & Tidak Tuntas \\
22 & 022 & 67 & Tuntas \\
23 & 023 & 67 & Tuntas \\
24 & 024 & 80 & Tuntas \\
25 & 025 & 60 & Tidak Tuntas \\
26 & 026 & 53 & Tidak Tuntas \\
27 & 027 & 60 & Tidak Tuntas \\
28 & 028 & 67 & Tuntas \\
29 & 029 & 67 & Tuntas \\
30 & 030 & 87 & Tuntas \\
31 & 031 & 73 & Tuntas \\
\hline
\end{tabular}

Rata-rata nilai prestasi belajar siswa pada siklus I adalah 63,84. Rata-rata persentase nilai prestasi belajar siswa setelah diterapkan model pembelajaran Make-A Match pada siklus I adalah 63,84 \% dengan kategori "kurang". Kendala-kendala yang ditemukan saat penerapan model pembelajaran Make-A Match pada siklus I adalah 1). siswa belum mampu mengkondisikan kelompok dalam mencari pasangan kartu dari yang didapatnya, 2). Siswa merasa masih bingung dalam kegiatan mencari pasangan kartu yang diperolehnya, 3). Model Make-A Match masih baru untuk anak kelas I di SD Negeri 4 Kaliuntu sehingga siswa harus dituntun dengan pelan-pelan agar siswa lebih memahami pembelajaran

Penelitian siklus II dilaksanakan pada Rabu 6 Februari 2019 sampai dengan Jumat, 22 Februari 2019. Siklus II dibagi menjadi tiga kali pertemuan yaitu pertemuan 1 dilaksanakan pada hari Rabu, 6 Februari 2019, pertemuan 2 dilaksanakan pada hari Jumat, 8 Februari 2019, dan tes siklus dilaksanakan pada hari Kamis, 14 Februari 2019.

Tabel 2. Nilai Prestasi Belajar Siswa Pada Siklus II

\begin{tabular}{cccc}
\hline No & Kode Subjek & Nilai & Keterangan \\
\hline 1 & 01 & 73 & Tuntas \\
2 & 02 & 100 & Tuntas \\
3 & 03 & 100 & Tuntas \\
4 & 04 & 75 & Tuntas \\
5 & 05 & 60 & Tidak Tuntas \\
6 & 06 & 93 & Tuntas \\
7 & 07 & 87 & Tuntas \\
8 & 08 & 74 & Tuntas \\
9 & 09 & 100 & Tuntas \\
10 & 010 & 80 & Tuntas \\
11 & 011 & 80 & Tuntas \\
12 & 012 & 75 & Tuntas \\
13 & 013 & 50 & Tidak Tuntas \\
14 & 014 & 87 & Tuntas \\
15 & 015 & 87 & Tuntas \\
16 & 016 & 50 & Tidak Tuntas \\
17 & 017 & 50 & Tidak Tuntas \\
18 & 018 & 87 & Tuntas \\
19 & 019 & 87 & Tuntas \\
20 & 020 & 73 & Tuntas \\
21 & 021 & 80 & Tuntas \\
\hline
\end{tabular}




\begin{tabular}{cccc}
\hline No & Kode Subjek & Nilai & Keterangan \\
\hline 22 & 022 & 67 & Tuntas \\
23 & 023 & 73 & Tuntas \\
24 & 024 & 87 & Tuntas \\
25 & 025 & 87 & Tuntas \\
26 & 026 & 80 & Tuntas \\
27 & 027 & 87 & Tuntas \\
28 & 028 & 90 & Tuntas \\
29 & 029 & 85 & Tuntas \\
30 & 030 & 100 & Tuntas \\
31 & 031 & 85 & Tuntas \\
\hline
\end{tabular}

Rata-rata nilai prestasi belajar siswa pada siklus II adalah 80,19. Rata-rata persentase nilai prestasi belajar siswa setelah diterapkan model pembelajaran Make-A Match pada siklus II adalah 80,19\%. Pada siklus II, rata-rata persentase nilai prestasi belajar siswa mencapai 80,19 \% dengan kategori "baik". Adapun beberapa peningkatan yang ditunjukan pada siklus II adalah sebagai berikut : 1). Siswa mampu mencari pasangan sesuai dengan kartu yang diperolehnya, 2). Siswa lebih aktif dalam mengikuti pembelajaran sehingga kelas menjadi aktif, 3). Interaksi yang terjadi multi arah yaitu baik siswa dengan siswa maupun siswa dengan guru.

Berdasarkan hasil penelitian siklus 2 yang telah diuraikan di atas, menunjukkan peningkatan yang signifikan pada aspek peningkatan prestasi pada siswa. Untuk lebih jelasnya perbandingan skor prestasi siswa pada siklus 1 dan siklus 2 dengan menggunakan model pembelajaran Make-A Match dapat dilihat pada tabel dan grafik sebagai berikut.

Tabel 3. Perbandingan nilai prestasi belajar pada Siklus 1 dan 2

\begin{tabular}{llll}
\hline No & Kode Subjek & Nilai Siklus I & Nilai Siklus II \\
\hline 1 & 01 & 53 & 73 \\
2 & 02 & 80 & 100 \\
3 & 03 & 80 & 100 \\
4 & 04 & 67 & 73 \\
5 & 05 & 53 & 60 \\
6 & 06 & 80 & 93 \\
7 & 07 & 73 & 87 \\
8 & 08 & 53 & 73 \\
9 & 09 & 93 & 93 \\
10 & 010 & 73 & 80 \\
11 & 011 & 67 & 80 \\
12 & 012 & 47 & 73 \\
13 & 013 & 33 & 53 \\
14 & 014 & 67 & 87 \\
15 & 015 & 73 & 87 \\
16 & 016 & 40 & 53 \\
17 & 017 & 40 & 53 \\
18 & 018 & 73 & 87 \\
19 & 019 & 53 & 87 \\
20 & 020 & 47 & 73 \\
21 & 021 & 53 & 80 \\
22 & 022 & 67 & 67 \\
23 & 023 & 67 & 73 \\
24 & 024 & 80 & 87 \\
\hline
\end{tabular}




\begin{tabular}{llll}
\hline No & Kode Subjek & Nilai Siklus I & Nilai Siklus II \\
\hline 25 & 025 & 60 & 87 \\
26 & 026 & 53 & 80 \\
27 & 027 & 60 & 87 \\
28 & 028 & 67 & 93 \\
29 & 029 & 67 & 87 \\
30 & 030 & 87 & 100 \\
31 & 031 & 73 & 80 \\
\hline Rata - rata & & 63,84 & 80,19 \\
\hline
\end{tabular}

Berdasarkan Tabel 3 terlihat perbandingan antara pelaksanaan siklus 1 dan 2. Pada siklus 1 terdapat 13 siswa yang mendapat nilai di bawah KKM sedangkan pada siklus II hanya terdapat 4 siswa yang tidak tuntas. Terdapat peningkatan persentase prestasi belajar siswa dari $63,84 \%$ meningkat menjadi $80,19 \%$. berikut.

Untuk lebih jelasnya, perbandingan nilai prestasi belajar siswa dapat dilihat pada gambar 1, sebagai

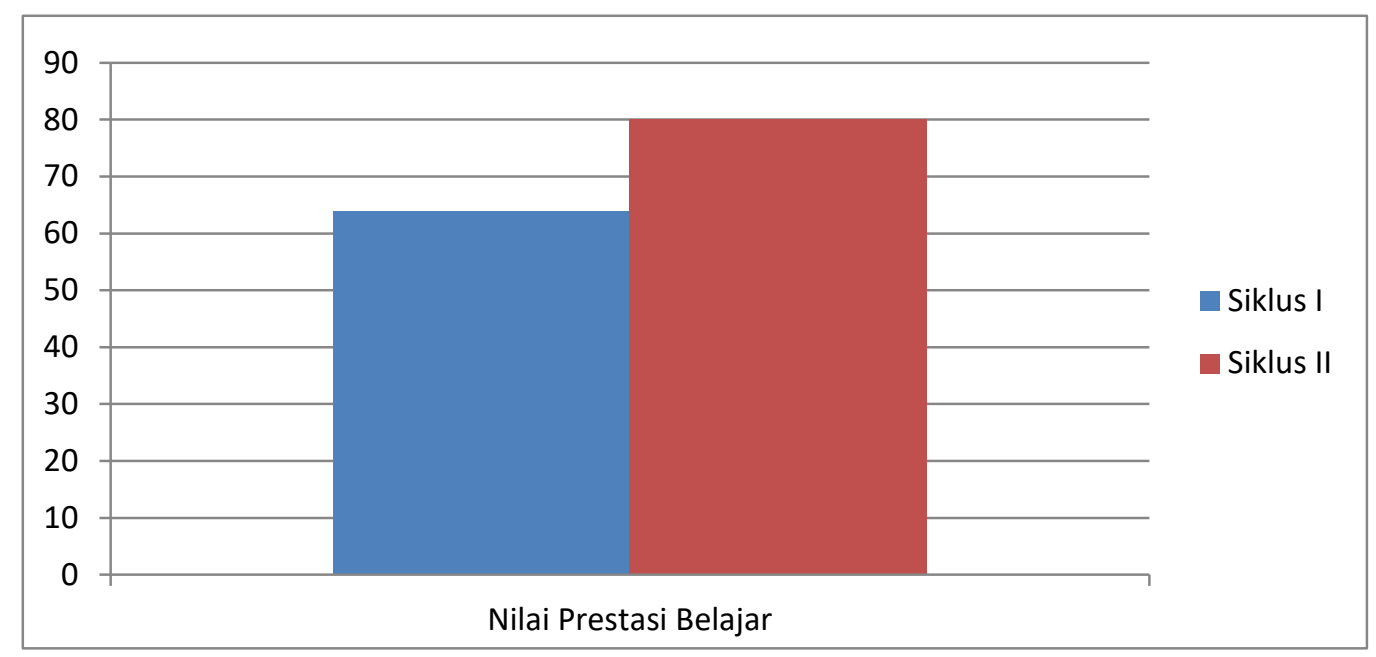

Gambar 1. Grafik perbandingan prestasi belajar siswa pada siklus I dan siklus II

Berdasarkan analisis pada siklus I yaitu persentase prestasi belajar siswa mencapai 63,84\%. Presentase ini menunjukkan pada PAP Skala Lima tergolong kurang. Sedangkan pada Siklus II presentase prestasi belajar siswa mencapai 80,19\%. Persentase ini menunjukkan pada PAP Skala Lima tergolong baik. Jadi prestasi belajar dari siklus I ke siklus II terjadi peningkatan sebesar 16,35\%. Hasil penelitian menunjukkan bahwa prestasi belajar siswa pada siklus I belum mencapai KKM yang ditetapkan yaitu minimal 65. Hal ini disebabkan karena adanya beberapa kekurangan.

Kekurangan-kekurangan pada siklus I adalah 1) Siswa belum mampu mengkondisikan kelompok dalam mencari pasangan kartu dari yang didapatnya.2) Siswa merasa masih bingung dalam kegiatan mencari pasangan kartu yang diperolehnya. 3) Model Make-A Match masih baru untuk anak kelas I di SD Negeri 4 Kaliuntu sehingga siswa harus dituntun dengan pelan-pelan agar siswa lebih memahami pembelajaran.

Berdasarkan kekurangan-kekurangan yang menyebabkan belum tercapainya kreteria keberhasilan yang ditetapkan, maka diadakan penyempurnaan pada siklus II yaitu 1) siswa diajak lebih semangat untuk belajar, 2) dalam kegiatan proses belajar dibantu dengan media power point, 3) guru lebih memahami dan mendalami bagaimana mengajar dengan menggunakan model Make-A Match sehingga diharapkan lebih menegaskan dan memperjelas langkah-langkah pembelajaran agar siswa melakukan kegiatan sesuai dengan langkah-langkah pembelajaran Make-A Match. Dengan melakukan upaya-upaya perbaikan tersebut, maka pada siklus II prestasibelajar siswa mengalami peningkatan dan telah mencapai kreteria keberhasilan yang ditetapkan. Terjadinya peningkatan prestasi belajar di siklus II pada penelitian tindakan kelas ini disebabkan oleh implementasi model Make-A Match yang lebih efektif. Terjadinya peningkatan pada siklus II ini juga karena guru sudah mampu memahami bagaimana cara melaksanakan proses pembelajaran dengan menggunakan model Make-A Match. 


\section{Simpulan Dan Saran}

Penerapan model pembelajaran Make-A Match di kelas I di SD Negeri 4 Kaliuntu dapat meningkatkan prestasi belajar siswa. Hal ini terbukti dari semakin meningkatnya skor rata-rata nilai tes siswa. Pada siklus I skor rata-rata nilai tes siswa sebesar 63,84 berada dalam kategori kurang, sedangkan rata-rata yang diperoleh siswa pada siklus II sebesar 80,19 berada dalam kategori baik. Ini berarti bahwa terdapat peningkatan keterampilan belajar siswa dari siklus I ke siklus II sebesar 16,35.

Berdasarkan hasil penelitian ini, peneliti dapat menyampaikan beberapa saran sebagai berikut: Bagi siswa kelas I agar saat mengikuti proses pembelajaran dapat menyiapkan diri dengan baik sehingga lebih cepat memahami penjelasan dari guru. Jika hal ini dapat terlaksana, maka besar kecenderungan prestasi belajar siswa akan meningkat. Bagi guru SD Negeri 4 Kaliuntu disarankan agar menerapkan model pembelajaran Make-A Match ini secara berkelanjutan karena memiliki keunggulan dan dapat meningkatkan prestasi belajar siswa. Melalui langkah-langkah pembelajaran yang tepat, diharapkan tercipta suasana yang menyenangkan dan tanpa ada perasaan tegang sedikit pun pada saat pembelajaran berlangsung. Selain itu, guru harus senantiasa memotivasi siswa untuk terus meningkatkan pengetahuan dengan cara lebih banyak membaca buku, bertanya, dan berdiskusi sehingga memudahkan siswa memahami informasi lainnya. Bagi kepala Sekolah SD Negeri 4 Kaliuntu agar dapat membantu guru dalam menyediakan sumber-sumber belajar yang menunjang dalam pembelajaran. Bagi peneliti lain agar mampu melaksanakan penelitian lebih lanjut dengan mengambil pokok bahasan lain sehingga diperoleh hasil yang lebih meyakinkan tentang penerapan model pembelajaran Make-A Match.

\section{Daftar Rujukan}

Agung,A.A.Gede. 2010. Pengantar Evaluasi Pendidikan. Singaraja: fakultas Ilmu Pendidikan Universitas Pendidikan Ganesha Singaraja.

Agung, A. A. Gede. 2005. Metodelogi penelitian pendidikan. Singaraja: IKIP Negeri Singaraja.

Dewey Jonh, 2000. Berpikir adalah bertanya . tersedia dalam http://www.sekolahdasar.net/2012/04/tujuan-dan-fungsi pembelajaranbahasa.html. (Diakses tanggal 12 Oktober 2015).

Deschuri, Cani. 2016. Penerapan Model Kooperatif Teknik Make A Match Dengan Media Kartu Klop Untuk Meningkatkan Hasil Belajar Siswa Pada Materi Kenampakan Alam Dan Buatan . Jurnal Pena Ilmiah: Vol. 1, No. 1 (2016)

Farhan. 2011. "Model Pembelajaran Kooperatif Tipe Snowball Throwing". Tersedia pada http://www.farhan-bjm.web.id/2011/09/model-pembelajaran-kooperatif - tipe.html?m=1 (diakses tanggal 12 Maret 2012).

Gagne dalam Suprijono ,2009:2. “ Penerapan Model Pembelajaran Kooperatif Tipe Berpasangan (Make A Match) Pada Mata Pelajaran IPA Materi Klasifikasi Mahkluk Hidup Untuk Meningkatkan Hasil Belajar Di SMPN 1 Gondang” "3.212 Jurnal Pendidikan Matematika dan Sains Edisi 34 Tahun ke-5 2016

Kurniasih dan Sani ,2015:56. "Pengaruh Model Pembelajaran Make A Match Terhadap Hasil Belajar Siswa Peningkatan Motivasi Belajar Siswa Menggunakan Model Make A Match Pada Pelajaran IPA Kelas V". JPGSD. Volume 06 Nomor 05 Tahun 2018, 640-649

Mifathul Huda,2012:135."Penerapan Model Pembelajaran Kooperatif Teknik Make A Match Untuk Meningkatkan Motivasi Dan Prestasi Belajar Akuntansi Siswa Kelas X AK SMK Uhammadiyah 2 Yogyakarta Tahun Ajaran 2014/2015".

Mulyana, Aina. 2012. Kemampuan Bertanya Pada Siswa. Tersedia dalam http://ainamulyana.blogspot.com/2015/02/kemampuan-bertanya-pada-siswa.html (diakses tanggal 12 Oktober 2015).

Nurkancana, Wayan dan Sunartana. 1990. Evaluasi Hasil Belajar. Surabaya: Usaha Nasional. 
Purnomo, M. 2011. Pengertian Keterampilan Bertanya. Tersedia: http://maspurnomo.wordpress.com/2011/10/31/pengertian-ketrampilan-bertanya/ (diaskes tanggal 12 Oktober 2015).

Rahmawati, Tutik. 2013. Pengelolaan Pembelajaran Tematik Terpadu. Malang: PPPPTK BOE Malang.

Riyanti, Nisrohah Neni. 2018. Penerapan Model Pembelajaran Kooperatif Tipe Make A Match Untuk Meningkatkan Hasil Belajar Ips . JPGSD, Volume 06 Nomor 04 Tahun 2018

Rusman,2012. "Penerapan Model Pembelajaran Kooperatif Tipe Make A Match Untuk Meningkatkan Hasil Belajar IPA Siswa Kelas Vi Sd Negeri 006 Tri Mulya Jaya Kecamatan Ukui". Jurnal Primary Program Studi Pendidikan Guru Sekolah Dasar Fakultas Keguruan dan Ilmu Pendidikan Universitas Riau| Volume 5 | Nomor 3 | Edisi Khusus HUT PGRI Ke-71 Tanggal 25 November 2016 | ISSN: 2303-1514 |

Safitri, 2011.Model Pembelajaran Snowball Throwing untuk Meningkatkan Hasil Belajar Matematika. Tersedia pada file:///C:/Users/user/Documents/ kelebihan\%20s\%20Throwingg.htm (diakses tanggal 13 Maret 2012).

Sudjana, Nana. 2006. Penilaian Hasil Proses Belajar Mengajar. PT Remaja Rosdakarya: Bandung.

Sudjana,2010."Penerapan Model Make A Match Dalam Upaya Peningkatan Hasil Belajar IPS Siswa" Wacana Akademika Volume 1 No 2 Tahun 2017

Suprijono, Agus. 2009. Cooperative Learning (Teori dan Aplikasi Paikem). Pustaka Pelajar: Surabaya.

Wina ,2016: 2. "Model Pembelajaran Kooperatif Tipe Make A Match Berbantuan Kartu Bergambar Untuk Meningkatkan Hasil Belajar Siswa" Jurnal Bidang Pendidikan Dasar (JBPD), Vol.2 No. 1 A April 2018 http: ejournal.unikama.ac.id/index.php/JBPD

Wiraatmadja, 2007. "Penerapan Model Pembelajaran Make A Match Dengan Media Kartu Bergambar Untuk Meningkatkan Motivasi Dan Hasil Belajar Siswa" 